\title{
MYTH AND FOLKLORE EMBODIMENT IN THE FEMALE PROTAGONISTS OF CONTEMPORARY FICTIONS: A READING OF THE SHIVA TRILOGY AND BULBBUL
}

\author{
Prasadita L. Raveendran \\ Guest Faculty Department of English, Mangalore University Karnataka \\ Email: prasadita86@gmail.com
}

\begin{abstract}
The collective consciousness of a community is tremendously shaped by myths and folktales passed on from generation to generation. With the publication of Joseph Campbell's book The Hero with a Thousand Faces, the idea of the hero and his journey took a giant leap, allowing the commoner's life narratives to be equated with the mythical journey. This study analyzes how mythology is demythified and symbolically represented in two of India's famous narratives, a novel series Shiva Trilogy by Amish Tripathi and an "over-the-top" (OTT) film Bulbbul by Anvita Dutt. The objects of this research are Indian mythological narratives about Goddess Shakti and her various manifestations - Durga, Kali, Sati, and Parvati — whose respective nature and purpose differ vastly from one another. Through the qualitative research method, the paper shows that the reader/viewer has well-received the interweaving of myth with contemporary fiction. It has given way to a change in diegesis, from the predominantly male-hero-focused outline to a female-driven narrative. The myth-bound heroines thus represent the power to break the shackles of patriarchy and normative culture, allowing an area for women to radicalize themselves through bold actions.
\end{abstract}

Keywords: Indian mythology, folktales, demythification, Shakti, radical

\begin{abstract}
ABSTRAK
Kesadaran kolektif suatu komunitas sangat bergantung pada mitos dan cerita rakyat yang diturunkan dari generasi ke generasi. Dengan diterbitkannya The Hero with a Thousand Faces karya Joseph Campbell, gagasan tentang pahlawan dan perjalanannya memungkinkan narasi kehidupan orang biasa untuk disejajarkan dengan perjalanan mitos. Studi ini bertujuan untuk menganalisis bagaimana mitologi didemistifikasi dan secara simbolis direpresentasikan dalam dua narasi terkenal India, yakni serial novel Shiva Trilogy karya Amish Tripathi dan film "over-the-top" (OTT) Bulbbul karya Anvita Dutt. Objek penelitian ini adalah narasi mitologi India tentang Dewi Shakti dan berbagai manifestasinya — Durga, Kali, Sati, dan Parvati — yang sifat dan tujuannya masing-masing sangat berbeda satu sama lain. Melalui metode penelitian kualitatif, ditemukan; 1) pembaca/pemirsa telah menerima dengan baik jalinan mitos dengan fiksi kontemporer; 2) memberi jalan pada perubahan diegesis, dari garis besar yang berfokus pada pahlawan pria menjadi narasi yang digerakkan oleh wanita; 3) para tokoh wanita yang terikat mitos, mematahkan belenggu patriarki dan budaya normatif, memungkinkan area bagi perempuan untuk meradikalisasi diri mereka sendiri melalui tindakan yang berani.
\end{abstract}

Keywords: Mitologi India, cerita rakyat, demitifikasi, Shakti, radikal 


\section{INTRODUCTION}

A nation is built on its myths and folklore. Even in the present era of technology and modernity, myths and fables can change public perception. As such, the societal construction of femininity to mythological figures as being humble, meek, ever-nurturing, kind, and caring encompasses just one dimension of the multi-faceted Hindu goddess Shakti. Of her innumerable personas, Durga, Parvati, Kali, Mahishasuramardhini, Mahamaya, Sati are but a few names. When it comes to worshipping this powerful goddess, her devotees, irrespective of gender, fervently pray to her in awe and fear. As an extension of religious and social conventions, the domesticated incarnation of the goddess is lauded when a woman in real life carries out domestic responsibilities with utmost devotion and precision. Considered to be the embodiment of the ideal woman, she would be referred to as SatiSavitri, a commended age-old name that furthers the image. However, ironically, when the same woman tries to adhere to the aggressive principles of Durga or Kali, she would be frowned upon by her loved ones and/or shunned by the community, citing that she has gone astray and can incite 'wrongful' behaviors in other women. Typifying a woman as an outcast or an aberration for not neatly fitting into the 'normal' web has been a practice ingrained since time immemorial in myths and fictions. However, twenty-first-century India, embracing liberal feminist tendencies, is more open - albeit slowly - to a more radical outlook on women. In fiction, this welcoming stance has paved the way for the retelling of myths about women or their symbolic goddess representations. Two of India's more recent popular fictional narratives, namely Amish Tripathi's Shiva Trilogy (Tripathi, 2010, 2011, 2013) and Anvita Dutt's "over-the-top" (OTT) film Bulbbul (2020), evoke the images of Goddess Shakti through its heroines, and the wide public acceptance of these heroines has opened new horizons for more female justice/vengeance-driven narratives.

In his hero-manifesto The Hero with a Thousand Faces (2004), Joseph Campbell delineates the journey of a hero. The archetypal image of a hero often encounters a woman in his quest for good or retribution. She can either be a guiding spirit, like a helpful goddess, or a femme fatale, a temptress who misguides the hero. Rarely is the 'hero' the woman. Nonetheless, if the hero is a female, there is usually a gender reversal regarding the guiding/tempting spirit. The fact ought to be considered that although the term 'hero' is gender-neutral and can therefore be synonymously used for 'heroine' when it is viewed by the reader/viewer, the connotation of a male figure is the obvious thought process. Thus, it is no wonder that when in need of a savior, the fictional and the real world alike often, if not always, immediately look for a male authority figure. To count the innumerable tales where a male hero proves his might would be a tiresome undertaking. However, look for narratives in which a woman is considered as the hero or the main protagonist or at least a character who has as much footing and voice as the male hero, and the number quickly dwindles. It is usually popular fictions that significantly sway the masses and bring forth changes in society and its outlooks; thus in this sense, the Shiva Trilogy and Bulbbul take precedence.

It cannot be claimed that these titles are the only fictional narratives that borrow from Indian mythology and folklore to navigate the tales of powerful women. Therefore, to critically read these works, a qualitative approach - comparative reading, recognizing metaphorical representations in mythological terms, and note-taking (not only of the retold texts but also of the fundamental mythological folklorish texts) - becomes a vital part of this study. More recently, Indian mythological fictions which emphasize women's stories have grown significantly, with notable works such as The Palace of Illusions by Chitra Banerjee Divakaruni, The Liberation of Sita by Volga, The Hastinapur Series by Sharath Komarraju, Karna's Wife: The Outcast Queen by Kavitha Kane, and Sita: An Illustrated Retelling of the Ramayana by Devdutt Pattanaik. The film industry has also borne witness to female-centric narratives, although most may not establish any supernatural or mythological link to the plot. Films like Phoolon Devi (1985), 22 Female Kottayam (2012), Maatr (2017) best exemplify the genre of a woman's vigilantism against perpetrators of the protagonist herself or her loved ones. These films served as stepping stones for the taking of a wider stance on such a genre that ultimately blend its narratives with mythology and folklore. The 2017 Kannada film Shuddhi and the more recent Bulbbul carry forward the female vigilantism narrative by putting it in a mythological framework. Such a strategy can leave a deeper impression on the Indian audience who have been brought up on Indian 
cultural and mythological narratives since childhood, enabling the people to recognize the harsh realities of patriarchy and women's capability to rise far above the restrictive norms of society.

\section{METHODS}

This study was conducted through qualitative research using thorough data analysis to interpret and re-interpret the already established meanings in the texts. The study focused on Amish Tripathi's novels in the Shiva Trilogy, namely The Immortals of Meluha, The Secret of the Nagas, and The Oath of the Vayuputras, and Anvitta Dutt's directorial OTT release Bulbbul. Tripathi's novels are set in a fictional world within old India with most of its events revolving around the citizens of one of its major kingdoms, Meluha. To analyze the feminine power dynamics in sync with the world of mythology, only two characters, Sati and Kali, were selected as the objects of focus from this first text. The second text (film), Bulbbul, presented a supernatural folktale and its protagonist act as this study's other main object. To conduct the qualitative research, the researcher combined two types of analysis - comparative analysis and metaphorical reading of texts - with points of reference not restricted to the two primary texts. Thus oral, scriptural, and religious conventions passed from generation to generation were also analyzed to understand the collective consciousness. This was done to see how certain values have been borrowed by the main texts in order to befit the contemporary period and stimulate a radical and liberal spirit amidst the people.

\section{FINDINGS AND DISCUSSION}

The result and discussion of this research are divided into four parts. The first part briefly introduces the points of reference regarding four specific forms of Goddess Shakti, which is required by the comparative part of the study on the mythological elements of the texts. The second and third part compares and contrasts Goddess Kali's characteristics, actions, and major life events with Tripathi's Queen Kali; and Goddess Sati, Goddess Durga and Goddess Parvati with Tripathi's Princess Sati, respectively. The last portion details the folk myth blend in Bulbbul's protagonist Bulbbul, drawing from the supernatural fable of the chudail and the mythical incarnation of Goddess Kali. Though Joseph Campbell has been used to understand the steps a hero has to go through to achieve their goal, the discussion mainly incorporates opinions and arguments raised by David R. Kinsley and Devdutt Pattanaik about the portrayal of the goddesses in Hindu mythology.

\section{Durga, Kali, Sati, and Parvati: The Many Avatars of Shakti}

India is deep-rooted in its spirit of religion, tradition, and myths. To trace Indian mythology means to come across the multitude of gods and goddesses of the Hindu pantheon. Every god and goddess has multidimensional images with varied stories of origin, history, and purpose. The Trinity or the Trimurti Brahma (the creator), Vishnu (the preserver), Shiva (the destroyer) - are considered to be the supreme divinities in Hinduism for their roles in maintaining cosmic balance. They are believed to provide aid to their devotees in fighting the evil that haunts the three worlds, either on their own or through their various avatars. These divine stories are known to men through the Upanishads, the religious Vedic Sanskrit texts of Hinduism. One of the most astonishing facts about the Upanishads is that of the many texts, the only group of Upanishads about a goddess and not a god is called Shakta Upanishads, which talk about Shakti. Along with this text, the widely read Devi Mahatmayam, another religious text on the Goddess Shakti, gives a detailed narration of the Goddess's supreme powers. The texts describe her as the creator of the universe and portray her numerous forms, deeds, battles, and generosity. She is considered to be all-powerful and capable of slaying demons to maintain peace and balance. Therefore, when a parallel is drawn between Shakti and the Trinity, it can be said that she is quite similar to them in powers and actions. She is both a preserver and a destroyer. Hence it is also generally acknowledged that the power of the Trinity can take its true form only with Shakti for She is His counterpart. Without Her, the Trinity would be "ineffective, weak, and immobilized" (Kinsley, 1988: 104).

Hindu devotees worship all and specific deities, but some of the most common gods and goddesses to be worshipped fervently include Krishna, Ram, Ganesh, Hanuman, Durga, and Kali. In fact, two of the most worshipped forms of Goddess Shakti are Durga 
and Kali, who are the epitome personifications of warrior goddesses. The following is how David R. Kinsley, in his work Hindu Goddesses: Visions of the Divine Feminine in the Hindu Religious Tradition, describes her:

Her primary mythological function is to combat demons who threaten the stability of the cosmos. In this role, she is depicted as a great battle queen with many arms, each wielding a weapon. At a certain point in her history, Durga becomes associated with the God Siva as his wife. In this role, Durga assumes domestic characteristics and is often identified with the Goddess Parvati. She also takes on the role of mother in her later history. At her most important festival Durga Puja, she is shown flanked by four deities identified as her children: Karttikeya, Ganesa, Sarasvati, and Laksmi. (Kinsley, 1988: 95)

Durga and Kali, in their primary roles, are women of tremendous physical strength. This nature might be in stark contrast to the other goddesses whose predominant virtues are more chaste, wifely, and motherly, such as those of Shakti's other forms, Sati and Parvati. Sati, the first wife of Lord Shiva, symbolizes India. It is told that after her death, her body parts were scattered throughout India. Wherever it fell, the location became sanctified. Reverentially known as pitha, these places eventually drew devotees to pray to their different goddesses of different names. In such sense, Sati denotes a life force and acts as an object of death (Pattanaik, 2000). On the other hand, Parvati is an avatar of Shakti who symbolizes love, beauty, children, harmony, and marriage. She is the second wife of Shiva.

October in India sees a nine-day celebration devoted to Durga with displays of the power of the feminine among the people. These nine days, known as Navaratri or Dussera, are a time of celebration and joy. This period is particularly reserved to extol the victory of good over evil. Hence, in works of fiction that idolize these goddesses as embodying mortal qualities, a deep envisioning of liberation occurs.

\section{Demythifying Kali in the Shiva Trilogy as A Fearsome Warrior with Physical Impairments}

As one of the main characters who hold exceptional power, intellect, skills, and stature in Tripathi's widely celebrated novels of the Shiva Trilogy, Queen Kali strikes a sharp resemblance to Goddess Kali in Indian mythology. Be it the looks, the fierceness of her eyes, her brash attitude, and her desire for wreaking havoc upon those who do wrong, Tripathi successfully blends the mythological image of Goddess Kali into the character of Queen Kali, but at the same time demythifies her by portraying her as a mortal being. In The Secret of the Nagas, Tripathi details Queen Kali's physique as such:

Her entire torso had an exoskeleton covering it, hard as bone. There were small balls of bone that ran from her shoulders down to her stomach, almost like a garland of skulls. On top of her shoulders were two small extra appendages, serving as a third and fourth arm. One was holding a knife, clearly itching to fling it at Sati. But it was the face that disturbed Sati the most. The colour was jet black, but the Naga Queen's face was almost a replica of Sati's (Tripathi, 2011: 187).

The colour of Queen Kali's face is said to be "jet black," just like that of Goddess Kali. Goddess Shakti/Durga created the archetypal Goddess Kali of the Indian mythology out of her wrath, giving her a terrible appearance that is beyond frightening. Tripathi's descriptions of the physical features of Queen Kali also characterize a fearsome individual who has bloodlust and is eagerly waiting for the first chance to throw a knife at her enemy. In mythology, Goddess Kali is described as being "adorned with severed arms as a girdle, freshly cut heads as a necklace ... having clawlike hands with long nails" (Kinsley, 1988: 116). In the novels, Queen Kali's bones protrude from her shoulders, giving a similar appearance as having a skulls necklace due to the bizarre shape, especially since the "balls of bone" extend to her stomach. This image, without a doubt, immediately conjures the persona of the skulls-adorned Goddess Kali in the minds of Indian readers.

Similarly, Queen Kali's extra appendages mirror the multiple arms of Goddess Kali, even though for the queen it is a matter of physical deformity. These extra arms serve as a typification of the two sides of Goddess Kali: the benevolent and blissful arms on the right side, and the aggressive, weapon-wielding hands on her left side (Kinsley, 1988). Both Queen Kali and Goddess Kali 
are storehouses of negative energy, which is precisely why their skin is black. In Goddess Kali, the blackness represents her nature that craves for the destruction of evil, thus imbibing unto herself the negativity from the world. In Queen Kali, the colour of her skin is a direct result of the negative effects of a medicine called the somras, considered by the people of Meluha to be a drink of the divinities, capable of curing diseases and increasing longevity (Chaudhuri, 1956).

Tripathi's Kali is the Queen of the Nagas. The Nagas are outcasts that have been shunned from Meluha to Panchavati, or the land of the demons. This marginalised group is deemed unfit to mingle with society due to their physical impairments. The outgrowths that they have in the form of extra limbs or heads or other body parts are deemed by the God-fearing citizens of Meluha to be the results of the outcasts' sins from their past lives. Therefore, as a way of penitence, they have to stay away from normal people. Queen Kali, the disowned daughter of King Daksha and Queen Veerini of Meluha, is the twin sister of Sati, the Princess of Meluha and later the wife of Shiva. Kali later becomes a mother figure to Sati's son, Ganesha, who was also born with physical deformities and thus branded a Naga. Queen Kali is the ultimate personification of those who have fallen victim to the biased and prejudiced society of Meluha. The prejudice is evident when even the most powerful person of Meluha, out of fear of being looked down on by society and forced to give up his rights to the throne, decides to ship off one of his daughters to the world of the outcasts because she is 'unnatural.' (Dalmiya, 2000) In this act, a great irony lies. As per Meluhan law, the parents ought to accompany the child with the unnatural outgrowths to the land of the demons. However, as is the case with Daksha and Veerini, many parents ignore this law. The Meluhan king and queen choose to live in the comforts and luxuries provided by the kingdom instead. Daksha and Veerini further ensure that the whole matter of Sati's twin sister is covered up. Throughout the first novel, The Immortals of Meluha, this secret is never revealed - not to the readers nor to the other characters who are not directly associated with the Nagas. The connotation given to Panchavati as a paatal lok or land of the demons underscores the staunch belief of the Meluhan society, which brands the Naga children as demons. Out of their fear of the deformed human beings, they fail to realise that they are the ones with crooked morality and ethics. Society even ostracizes, if not completely then at least to an extent, those individuals who become physically impaired at a later stage in life. Blind men and women who give birth to stillborns or impaired children come under this 'Vikarma' categorization (Tripathi, 2010). Here, again, their unfortunate situation is blamed on their grievous crimes of past life, a life or action(s) for which the society has no proof. Thus, it can be established that the disability is not with the Naga children, but with the restrictive and narrow-minded Meluhans who refuse to accept and integrate the Nagas into their lives. The Meluhans' ideal lifestyle was unwelcoming to the plight and pain of physically impaired individuals. Tripathi emphasizes this ignorance of Meluhans by mildly pointing it out through the perspectives of Shiva and Queen Kali. They draw attention to how some revered figures such as Narasimha, an avatar of Lord Vishnu whose face resembled a lion, and Ravana, who had multiple heads, were also victims of somras, and how had they been alive within the timeframe of the Shiva Trilogy, they too would be isolated and branded as life's aberrations.

The mythical Kali is a sheer, all-ranging, allencompassing power. She is fiercely independent in her battles and fights head-on without holding back. Her major purpose is to destroy the evil of the world. Goddess Kali is also shown to be impetuous and vengeful when riled. There is a story of how she was once summoned by a group of criminals who were her devotees (Dalmiya, 2000). To appease Goddess Kali's thirst for blood, they decided to sacrifice a young Brahmin monk who was exceptionally virtuous and pious. The story takes an unexpected turn when the young man's saintliness scorched the goddess' statue. In a fit of rage, she decapitated them and drank their blood (Heaphy, 2017). Goddess Kali demonstrates a strong refusal to accept others' assumptions of her nature. Queen Kali of the Shiva Trilogy also shows similar traits. Her anger can be easily triggered by the misconducts of her subordinates, even when they do so unintentionally. Although she does not decapitate heads or drink blood, Tripathi's descriptions make it loudly apparent that her wrath is something that her people do not want to have to deal with. Even her own nephew/foster son Ganesh does not wish to anger his mausi (aunt). The outside world who know of her temperament refers to her as "an extremist harridan" (Tripathi, 2013: 34). 
Queen Kali's excellent strategic thinking can be seen when she cautiously takes Shiva and Sati's entourage to her kingdom in Panchavati, as well as in the many battle sequences in which she leads her army in The Oath of the Vayuputras. These serve as magnificent examples that laud not only her intellect but also her physical strength, prowess, and her adeptness at handling weapons. These skills make Queen Kali a formidable warrior whose sheer name evoke trepidation in her enemies. This feeling of awe/terror for Queen Kali is in line with the legends of Goddess Kali. It is this combination of skills, intimidating features, and feeling of vengeance that Queen Kali carries all the way to the land of Egypt to avenge the murder of her sister Princess Sati. Just as the mythological Kali emanated from Goddess Sati during the yagna (a fire ritual of offering worship to the gods) for avenging the insult to Lord Shiva and Goddess Sati by Daksha, which concluded with Goddess Sati's eventual protest by polluting the yagna grounds by sacrificing her life, Queen Kali heads a small platoon of warriors to torture and murder Swuth and his tribe, who had by siding with Princess Sati's father, Daksha, the King of Meluha, caused Sati's death.

\section{Tripathi's Princess Sati as a Demythified Sati, Durga, and Parvati}

The name 'Sati' reverberates back to the Indian mythological Goddess Sati, the beloved daughter of the great King Daksha and his queen Prasuti (Pattanaik, 2000). Tripathi's Sati has been created as a persona of Tripathi's imagination by blending Goddess Shakti's three forms - Goddess Sati, Goddess Durga, and Goddess Parvati. Tripathi's Sati is the daughter of Daksha and Veerini, the King and Queen of Meluha. Thus, like Goddess Sati, Princess Sati is also a treasured daughter who is showered with all the love, values, and boons of her country. Similar to the Indian mythology in which Goddess Sati marries one of the Trimurti, Shiva, Princess Sati marries Shiva, a man recognized by Meluha as their saviour (Prabavathi, 2020; Tripathi, 2010). In the mythology, only after Goddess Sati's death, after a period of long ascetic isolation by God Shiva, does he marry another one of Goddess Shakti's forms, namely Goddess Parvati. In the novel, Princess Sati is also known as 'Parvati', as a way of addressing the fact that Princess Sati is the Goddaughter of the highly respected and brave Commander of the Meluhan army, Parvateshwar. The name of Goddess Sati's reincarnated form, however, can be traced back to her father, King Himavan, whose name in Sanskrit means parvat or 'mountain' (Pattanaik, 2000).

One of the major reasons why myths that are female-centric are relegated is because of the intense volume of male-centric mythical narratives. In Campbell's analysis of the hero's journey, among the steps that a hero must overcome are the twofold "Meeting with the Goddess" and "Woman as the Temptress" (Campbell, 2004: vii). Another capacity in which a woman occurs is either as a wife/consort/aid to the hero or as another minor character. Thus, myths have since time immemorial glorified the domestic nature of women. Goddess Sati is also an embodiment of this stereotype. She is a devoted wife and later, as the reincarnated Goddess Parvati, a devoted mother as well. Goddess Sati's love for Lord Shiva is unconditional. She accepts him for who he is and follows him wherever he goes. Therefore, the meaning implied by 'Sati' as a devoted wife defines Goddess Sati's traits (Pattanaik, 2000). In a similar fashion, Tripathi's Sati is also enamored by Shiva, the 'uncouth barbarian' and follows him in his journey of fighting evil by travelling across India. But in the novels, in her capacity as a wife and mother, she is characterized as not merely a woman who is in constant agreement with her husband's point of view. She can form her own opinions and sometimes even challenges his, offering a different outlook on things. In this manner, she can become a source of unique insights, providing her own way of guiding Shiva in his mission to destroy evil. This construct elevates Princess Sati to a level equal to Shiva, hinting at the notion of Shiva-Shakti, wherein Lord Shiva and Goddess Shakti maintain the balance of the universe through their union of power.

Goddess Durga was created by the Trimurti with their own unrestrained energy during a cosmic crisis that demanded a woman's power to destroy the evil that was haunting the world. She is the epitome of blinding light, beauty, and fierceness. Her superior power on the battlefield allows her to create "female helpers from herself" (Kinsley, 1988: 97). Goddess Kali is one such female helper. In the Shiva Trilogy, Sati is portrayed as a superior warrior akin to Goddess Durga. With the magnificent beauty, mutual veneration, and strategic manoeuvres that Princess 
Sati possesses, she can easily be compared to Goddess Durga. Thus, when Sati enters a battle, demythification is brought about through her shift from Goddess Sati's wifely nature to Goddess Durga's sense of autonomy and justice. This embodiment of Goddess Durga in Sati is highlighted in The Immortals of Meluha when Sati challenges Tarak for a one-on-one duel, but as he was not a personification of evil, she does not destroy him but instead chooses to forgive his ignorance. Goddess Durga, albeit a relentless warrior, is also known for her generosity and Sati mirrors this through her act of forgiveness.

In many respects, Durga violates the model of the Hindu woman. She is not submissive, she is not subordinated to a male deity, she does not fulfill household duties, and she excels as what is traditionally a male function, fighting in battle. As an independent warrior who can hold her own against any male on the battlefield, she reverses the normal role for females and therefore stands outside normal society. Her role provides a version of reality that potentially, at least, may be refreshing and socially invigorating (Kinsley, 1978: 99).

Princess Sati's valour is often applauded by many other characters in the novels. Yet, it is in the third novel of the series that her opponent's admiration for Sati's willpower, mesmerizing skills, and her determination to save her fellow men dominates. She battles a group of Egyptian assassins of the cult of Aten. As they exceed in number, she challenges them for the duel of Aten, a one-on-one battle. The way she fights with the utmost honour, bravery, and perseverance, commands respect and awe. The chief of the assassins, Swuth, immediately recognizes her courage, endurance, and might. He considers it an honour to fight Princess Sati, and he acknowledges this by worshipping her for the rest of his life as his final kill (Tripathi, 2013). Princess Sati, being a mortal, is killed, but she dies by embodying the pristine traits of Goddess Durga, who unlike Tripathi's Sati, is an immortal and a divine entity. In a way, Princess Sati brings forth Goddess Durga's aspect of being able to frequently inspire awe in her opponents. In Goddess Durga's case, her opponents usually fall for her beauty and magnificence, and would offer her a hand in marriage. However, at the outset, Goddess Durga would not appear to them to be a warrior who could defeat them. This misogynistic notion also acts on certain fronts as one of the reasons that lead to the demons' easy doom in mythology, simply because they underestimate her divine warrior-goddess power.

One of the grandest festivals celebrated across India is Navaratri, otherwise known as Durga Puja. The main theme of this festival revolves around the defeat of the demon Mahisa by Goddess Durga. It is a celebration of Goddess Durga's "role as a battle queen and the regulator of the cosmos" (Kinsley, 1997: 106). Although this is her dominant facet, Goddess Durga takes on other roles too, which are not often emphasized in Hindu religious texts, such as her domestic roles as a wife to Lord Shiva and a loving mother to her divine children. This manifestation of the maternal role of Goddess Durga, or when at such times Goddess Shakti can be better equated with Goddess Parvati, is shown by Sati through her nurturing care for Ganesh and Karthik. She is depicted as a mother who deeply loves her children and respects their personality, choices and wishes. Even in real life, many temples where Lord Shiva and Goddess Parvati are worshipped also have the idols of Lord Ganesha and Lord Kartikeya, the children of Shiva-Shakti. This domestic facet of Shakti's character is much praised during Durga Puja, as thousands of young married women in India would return to their home villages to celebrate the many personas of Goddess Shakti.

\section{Bulbbul, a Goddess-Kali Incarnation Branded as Chudail}

Bulbbul is set in Bengal in the pre-independence period. Therefore, its theme of the wronged being denied lawful justice due to lack of evidence or due to the societal relegation of terrible occurrences as being the result of some supernatural activity may fittingly seem like a thing of the past. But is it really? "Quite recently, during the 2016 Presidential elections in America, Hilary Clinton was called, "The Wicked Witch of the Left" (Roy, 2020). For radical and forward-thinking women who desire to break the boundaries of a normative society to be branded 'witches' is an age-old phenomenon. Both Eastern and Western analyses of the burning of 'witches' is ample proof of this. Ignoring evidence or lack thereof, once deemed guilty of practising witchcraft, women would be alienated from societal interaction or brutally murdered to reinforce patriarchal dominance and 
subjugation of women.

In India, a land steeped in folklore, the concept of witches, besides being used as a patriarchal tool, is sometimes also used to define the unknown. Churel or chudail is one such mythical demon-woman. She is an ill-omen and a vengeful spirit who desires the blood of not only family members who caused her death but also, if given the chance, goes on to lash out at her community for having victimized her. Dutt's Bulbbul works on this premise. Men living in the village of the heroine Bulbbul meet with terrible deaths, with much of their blood literally drained. All these points to the legend of the chudail, generally acknowledged as a demon by the patriarchal world. But the chudails's association with Goddess Kali also allows for a space to change their status from a demon to a dakini (energetic female spirit) who accompany Goddess Kali while she feeds on human flesh and blood. The Indian folktales of the dayans also follow a similar pattern of vengeful, fiendish female spirits who are dakinis.

The injustices that Bulbbul faced at a young age lead her to the realization that the crimes of her community ought to be punished - if not by law, then by outcasts. For Bulbbul, the manifestation of the outcasts takes the overt form of a chudail. However, as a paradox, in her covert form, is a Goddess Kali incarnation. As a child, Bulbbul was married to Indranil, who is much older than her. This led her to bond with her brother-in-law, Satya, who is closer to her age. Even if the age factor is taken out of the equation, Indranil keeps failing at understanding Bulbbul's aspirations and dreams. Years later, when Satya returns home, director Dutt presents the irony of the changes visible in both Bulbbul and Satya. The young woman has embraced her independence and role as head of the family, while the latter, as a subversion of his childhood and youthful liberal outlooks, has attuned himself to patriarchal regressive principles. The radical and liberal qualities now seen in Bulbbul are frowned upon by Satya, and he goes as far as trying to control her with the help of other people. One of the people who provide this help is another female figure belonging to the same household - a widowed woman by the name of Binodini, who was once married to a mentally challenged man Mahendra. However, Bulbbul manages to break all bondages imposed on her and roams free as chudail/Goddess Kali to slay the demons which harm the vulnerable.
The chudail's acts of murder are gruesome, for she drains the blood of her victims. As a scheme borne out of desperation to put an end to the slaughters, the villagers, headed by Satya, sets out on a 'witch hunt'. Chudail is known to punish abusers. Therefore, the chudail's justice system is welcomed by the abusers' victims, more or less in the same manner Goddess Kali is venerated for her bloodshed.

Bulbbul's transformation into a chudail allows the viewers to contemplate running a parallel to the typical femme fatale/dayan trope. Her appearance as a terrifying persona clad in obscurely short red cloth (hinting at an almost wholehearted acceptance of empowered nakedness), with loose, disheveled hair, twisted feet, as well as fiery eyes and blood-stained tongue and mouth, draws a striking resemblance not just to the prevailing image of a chudail but also to Goddess Kali. The film even validates this likeness to Goddess Kali by showing a small village temple for Kali worship when Bulbbul rises from the presumably dead state after a traumatic experience. As per the standard definitions of beauty, Bulbbul, portrayed by Tripti Dimri, has the looks for luring men. She thus carries the role of the temptress. On the other hand, Goddess Kali, unlike a femme fatale, is always sketched as a fearsome image rather than an appealing one. But Bulbbul's chudail's garb, although not an assortment of skulls and bones, dashingly flaunts the undisguised aspect that she holds close as opposed to the ostentatious attire of the thakurain (noble lady) that she wears in the normative culture. Her disordered hair is a symbolic representation of immense power and virility, a concept akin to Goddess Kali's. Bulbbul's explicit sexual drive is never shown or mentioned on screen, but she is a woman who dares to openly flirt with her close friend and doctor, Sudip, and desires more than mere companionship from her brotherin-law, Satya.

One of the most menacing characteristics of Goddess Kali is her blood-stained mouth and tongue. In mythology, when Goddess Durga is battling the demon Raktabija, she summons Goddess Kali to assist her. Raktabija has the unique capability to reproduce himself from his own blood, making his slaying problematic because his spilt blood allows him to regenerate himself over and over again. Goddess Kali then "defeats the demon by sucking the blood from his body and throwing the countless duplicate Raktabijas into her gaping mouth" (Kinsley, 1997: 118). Bulbbul 
conducts her mode of justice delivery by sucking the blood of her victims, who happened to be abusers, thus mirroring Goddess Kali's method of killing the demons. In one of Bulbbul's acts as a chudail/Goddess Kali, she kills a man in his bath, leaving a young girl as a witness to her actions. This young girl, when asked about the 'murderer', answers that it was the goddess herself who saved her. Likening Bulbbul to a goddess is done not just by this little girl but also by Sudip, who admires Bulbbul's acts of vengeance. But the idea that Bulbbul has epiphanic moments of possession by Goddess Kali only after being physically assaulted by her husband and sexually assaulted by her brotherin-law, Mahendra, indeed raises the question of the creation of a powerful woman only after she has been wronged. Nevertheless, Bulbbul's vigilante desire serves the chudail's/Goddess Kali's purpose of being a warrior spirit.

Bulbbul speaks volumes about the domestic and sexual abuses that the women in Bulbbul's village go through without really vehemently vocalizing it, but instead by dropping slight hints here and there. Bulbbul's own permanent physical impairment of the twisted feet as a result of her husband's torturous beatings allows the character to permeate the trope of chudails, also known for their twisted feet. The metaphors of feet reverberate throughout Bulbbul, starting from the first scene in which child-bride Bulbbul can be seen dangling her feet from a tree, portraying the freedom a little girl should be enjoying. This scene is soon shrouded by one where Bulbbul is forced to wear bichiyas (toe rings), which represent how a married woman is restricted by her husband and the society. This jump from freedom to restriction is also symbolized by the protagonist's very own name, which is also the name of a beautiful and freespirited bird. When doctor Sudip realizes that Bulbbul has become comfortable, or perhaps, even more comfortable in walking, running, and climbing trees with her twisted feet, the metaphor takes a drastically different turn. Like the power represented by Goddess Kali's feet, in terms of both her physical and sexual power, Bulbbul reenvisions her impairment as an empowering principle for herself. Strangely, from a non-mythological viewpoint, Bulbbul's transformative physical prowess can be viewed as a strong statement for breaking the shackles and even "turning the table" by pursuing aggressive vigilantism.

\section{CONCLUSION}

It is mostly during childhood that one is introduced to some of the most enchanting tales and myths, and these become forever etched in memory. The gods and goddesses, the supernatural entities, animals and plants, as well as the bizarre and fantastic places will seem fresh even as adults when probed tactfully because these stories not only amuse but also give a sense of understanding of life's principles, morals, values, and normativity.

Greek and Roman mythology are quite generally supposed to show us the way the human race thought and felt untold ages ago. ... [T] he real interest of the myths is that they lead us back to a time when the world was young and people had a connection with the earth. ... When the stories were being shaped, we are given to understand, little distinction had as yet been made between the real and the unreal. The imagination was vividly alive and not checked by the reason (Hamilton \& Savage, 1956: 11).

It is easy to associate the numerous happenings in our day-to-day life with myths. The various rituals, events or festivals, and beliefs that the present generation practices stem from a culture's mythology. This leads to linking the contexts and situations of many myths to the present day, thereby contemporizing mythological readings. It is exactly this contemporizing that has encouraged Amish Tripathi to endorse his female characters with the Vedic principle of equal authority, footing, and respect in all matters of life; be it education, choosing one's partner, or as this study emphasizes, the power to take on actions usually associated with masculinity such as striving for justice or meting out vengeance. Through Queen Kali and Princess Sati, the valour and might of a woman are brought forward, especially on the battlefield. Other facets which also determine their roles in society, which are generally viewed as the actions of the feminine, are also dabbled at, but since Queen Kali and Queen Sati are equated with Goddess Shakti's powerful avatars, irrespective of their roles, a mythological validation is permitted. Similarly, Anvita Dutt's Bulbbul also rises above the thakurain role she was initially bound to, becoming a free and radical woman who under the façade of the myths of chudail and Goddess Kali boldly protects the weak. These 
modernist interpretations of mythology and folktales allow women of society to look upon the mythological figures whom they worship and fear as representatives of the aggressive female empowerment.

\section{REFERENCES}

Campbell, J. (2004). The hero with a thousand faces (Commemorative Edition). Princeton: Princeton University Press.

Chaudhuri, A. K. R. (1956). A Psycho-analytic Study Of The Hindu Mother Goddess (Kali) Concept. American Imago, 13(2), 123-146. Retrieved from https://www.jstor.org/stable/26301373

Dalmiya, V. (2000). Loving Paradoxes: A Feminist Reclamation of the Goddess Kali. Hypatia, 15(1), 125-150. Retrieved from https://www.jstor.org/ stable/3810514

Dutt, A. (2020). Bulbbul [Drama, Horror, Mystery]. Clean Slate Films.

Hamilton, E., \& Savage, S. (1956). Mythology / S. Boston: Little, Brown and Company.

Heaphy, L. (2017). Kali - A Most Misunderstood Goddess. Retrieved June 24, 2020, from Kashgar website: https://kashgar.com.au/blogs/gods-goddesses/ kali-a-most-misunderstood-goddess

Kinsley, D. (1978). The Portrait of the Goddess in the
Devī-māhātmya. Journal of the American Academy of Religion, 46(4), 489-506. Retrieved from https://www.jstor.org/stable/1463045

Kinsley, D. (1988). Hindu goddesses: Visions of the divine feminine in the Hindu religious tradition. Berkeley, Calif.: University of California Press.

Kinsley, D. (1997). Tantric Visions of the Divine Feminine: The Ten Mahavidyas. California: University of California Press.

Pattanaik, D. (2000). The goddess in India: The five faces of the eternal feminine. Retrieved from https:// www.overdrive.com/search?q=3469AEF5-DE064172-ACE4-AD821F3D6090

Prabavathi, S. V. (2020). Recreation of Myth in Amish Tripathi's Shiva Trilogy. Journal of Xi'an University of Architecture \& Technology, XII(IV), 4230-4242. Retrieved from http://xajzkjdx.cn/gallery/415april2020.pdf

Roy, S. (2020, September 6). Film Analysis: Understanding Bulbbul. Retrieved June 18, 2021, from The ArmChair Journal website: https:// armchairjournal.com/understanding-bulbbul/

Tripathi, A. (2010). The immortals of Meluha. Chennai: Westland.

Tripathi, A. (2011). The secret of the Nagas. Chennai: Westland.

Tripathi, A. (2013). The oath of the Vayuputras. Chennai: Westland. 